\title{
Kompetencje negocjacyjne studentów a styl negocjacji i podatność na manipulacje
}

\author{
GRZEGORZ MYŚLIWIEC \\ Instytut Kapitału Ludzkiego, Szkoła Główna Handlowa w Warszawie
}

ADRIANNA ZAEĘGKA

Szkoła Główna Handlowa w Warszawie

Przedmiotem artykułu są schematy myślenia i działania umożliwiające organizowanie
rzeczywistości, które dają komfort zachowania w znanych sytuacjach, wydarzeniach czy
środowiskach. Skuteczność tych schematów zweryfikowano w odniesieniu do kompeten-
cji i doświadczeń negocjacyjnych w rozpoznawaniu i obronie przed manipulacją wśród
studentów i absolwentów uczelni. W badaniu ankietowym zastosowano testy reagowania
na konflikt i opisy 10 sytuacji manipulacyjnych. Badaniu poddano dwie grupy respon-
dentów - trenowanych negocjacyjnie oraz nietrenowanych i nienegocjujących zawodowo.
Wykazano, że grupa badawcza, do której należą członkowie i alumni organizacji związa-
nej z negocjacjami, uzyskała wyższe wartości punktowe przy stylach współdziałania oraz
kompromisu, a mniejsze w stylu rywalizacji niż grupa badawcza nietrenowana. Druga
część badania związana z manipulacjami dała wyniki bardzo zbliżone, wyraźnie poka-
zując, przy których technikach manipulacji badani mieli problem. Same wyniki przed- 
stawiały zadowalający poziom rozpoznania manipulacji wśród obu grup, w przybliżeniu wynosząc 6 rozpoznań na 10 podanych manipulacji.

Słowa kluczowe: kompetencje interpersonalne, manipulacja, negocjacje

Kod klasyfikacji JEL: M53

\section{W prowadzenie}

Kompetencje interpersonalne zawsze stanowiły wyzwanie dla badaczy i dydaktyków ze względu na ich ulotną strukturę i brak możliwości pełnego przewidzenia przebiegu oraz rezultatu działań edukacyjnych. Wydaje się, że tworzenie kompetencji miękkich to ciąg modyfikacji ocen i zachowań, przeważnie budowanych w większej lub mniejszej grupie, z efektami, których tylko kierunek podlega kontroli. Każdy człowiek zareaguje zgodnie ze swoją własną, niepowtarzalną specyfiką, a więc dołączy nowe doświadczenia (np. z gier negocjacyjnych) do swojego mindset, czyli zestawu schematów decyzyjnych i behawioralnych. W innym ujęciu jest to myślenie szybkie (decyzyjne) w odróżnieniu od wolnego (analitycznego). Gdy osoby poddane treningowi mają fixed mindset, silnie utrwalony, oporny na zmianę sposób myślenia, a inni growth mindset, nastawiony na zmianę, chłonący nowe doświadczenia, to uzyskane efekty mogą znacząco odbiegać od założonych.

W niniejszym artykule opisano próbę weryfikacji skuteczności doświadczeń negocjacyjnych w zakresie rozpoznawania i obrony przed manipulacją.

Część badawcza przygotowana została na podstawie dwuczęściowej ankiety badającej styl negocjacyjny oraz podatność na manipulację dwóch grup badanych - studentów i absolwentów trenujących negocjacje oraz nietrenujących negocjacji i zawodowo niezwiązanych z negocjacjami.

\section{Hipotezy:}

1. Dominujacym stylem grupy trenującej negocjacje jest styl wspótpracy, a najmniej dominującym - styl rywalizacji, co zwiqzane jest z posiadanq teoretycznq wiedzq. i doświadczeniami na temat korzyści płynących z takiego nastawienia.

2. Grupa trenujaca negocjacje odznacza się bardziej kooperacyjnym oraz kompromisowym stylem negocjacji niż nietrenujaca.

3. Grupa nietrenująca negocjacji będzie się odznaczała bardziej rywalizacyjnym stylem negocjacji niż grupa trenująca, co zwiq̨zane jest z tendencją ludzi do dążenia do wygranej oraz postrzegania konfliktu interesów $w$ kategorii "twój zysk = moja strata”.

4. Grupa trenujaca negocjacje lepiej wykrywa manipulacje, co zwiq̨zane jest z teoretycznq wiedzq na temat technik manipulacji; grupa niezwiq̨zana ze środowiskiem negocjacji - osiagnie słabsze wyniki w wykrywaniu manipulacji niż pierwsza. 


\section{Mechanizm manipulacji i perswazji}

Czym jest manipulacja? Należy odróżnić pojęcie manipulacji od pojęcia perswazji: oba odnoszą się do sztuki wywierania wpływu, czyli odczytywania ludzkich potrzeb, uświadamiania ludziom tych potrzeb i zaspokajania ich (Mayer, 2007, s. 36). Manipulację można określić jako wywieranie wpływu na drugą stronę w taki sposób, aby z własnej, nieprzymuszonej woli podjęła pożądane przez manipulatora działania (nie zdając sobie w pełni sprawy z ich konsekwencji), które przyniosą mu konkretną korzyść (Niemczyk, Kędzierski, 2014, s. 117). Największym, a według niektórych badaczy - jedynym, wyraźnym kryterium odróżniającym manipulację od perswazji są intencje osoby nakłaniającej (Lakhani, 2007). Gdy jedna strona dąży tylko i wyłącznie do osiągnięcia własnych korzyści - bez względu na drugą stronę, jej stratę, zranienie uczuć czy ogólne pogorszenie sytuacji - wtedy możemy określić ją mianem strony manipulującej.

Natomiast osoba używająca perswazji dąży do przekonania drugiej strony do jakiejś racji, przedstawiając ją w odpowiedni i zrozumiały dla niej sposób, ze swojego punktu widzenia, a w konsekwencji wpływa swoimi działaniami na zmianę opinii partnera, dając szansę na osiągnięcie obustronnych korzyści. Perswazja definiowana jest jako „nakłanianie do czegoś z zastosowaniem silnego nacisku na wyjaśnienie i argumentowanie potwierdzające słuszność" (Olechnicki, Załęcki, 1997, s. 153). Upraszczając, można przyjąć, że manipulacje są częścią nieetycznych zachowań, jakie mogą występować w negocjacjach, perswazja natomiast wpisuje się w ramy etycznego prowadzenia pertraktacji. E. Kowalczyk wskazuje jednak, że „etyka negocjacji ma charakter relatywistyczny, a nie absolutystyczny” - gdy negocjacje mają jasno wyznaczone reguły i zasady, a manipulacje nie naruszają granic wytyczonego przez negocjatorów pola gry, mogą być w danych negocjacjach dozwolone (Kowalczyk, 2017).

Kolejną różnicą między tymi dwoma pojęciami jest nastawienie na konsekwencję swoich działań oraz charakter współpracy w przyszłości. Negocjacje w wariancie długookresowym są dalekosiężnym procesem, który opiera się na zachowaniu dobrych stosunków pomiędzy wszystkimi stronami. Perswazja jest metodą wpływu, która nie zaszkodzi osobie przekonywanej w późniejszym czasie, co więcej - nie wpływa negatywnie na nią w momencie negocjacji. Manipulacja jednak ma przynieść jednej stronie doraźne korzyści tu i teraz, co implikuje jej krótkotrwały charakter, jako że osoba manipulowana nie będzie chciała podjąć współpracy z manipulatorem w przyszłości. O ile podczas manipulacji nie zdaje sobie sprawy z tego, że jest podporządkowywana (Lewicki i in., 2005, s. 32), tak już podczas samych negocjacji manipulacja może wywołać nieprzyjemne reakcje (często nieświadome, jak np. reakcje fizjologiczne). 
Dlatego też różnice między manipulacją a perswazją można rozpoznać po odczuciach drugiej strony związanej z sytuacją i osobą potencjalnego manipulatora.

Bardzo często osoba zmanipulowana:

- czuje się nieswojo,

- czuje się przymuszona do zrobienia czegoś,

- robi coś wbrew sobie, swoim przekonaniom czy interesom,

- ma żal do manipulatora i staje się wobec niego nieufna,

- odczuwa złość na siebie, np. za zgodę na niekorzystne dla niej warunki,

- unika ponownych kontaktów z drugą stroną,

- traci pewność siebie (Niemczyk, Kędzierski, 2014, s. 117).

Sugeruje się również obserwację własnych uczuć w celu lepszego wykrywania manipulacji (Ury, 2006, s. 56). Każdy z negocjatorów jest podatny w jakiś sposób na emocje. Dobrą podpowiedź mogą stanowić automatyczne reakcje organizmu, które zasugerują, że coś jest nie tak, zanim to sobie uświadomimy. Są to sygnały np. w postaci potliwości, kołatania serca, czerwienienia się. Może to być pierwsza informacja, że druga strona wpływa negatywnie na nasze samopoczucie.

Jak się bronić przed manipulacją?

Strony negocjacji, które poddane są działaniom manipulacyjnym, często instynktownie reagują kontratakiem, ustąpieniem lub zupełnym zerwaniem rozmów. Kontratak jednak może prowadzić do eskalacji konfliktu, co tylko utrudnia lub uniemożliwia dalsze rozmowy. Ustąpienie ze stanowiska jest z kolei zachowaniem pożądanym przez manipulatora, oznacza podporządkowanie się, aby zakończyć nieprzyjemną sytuację. Zerwanie rozmów jest lepszym zachowaniem, ale nie zawsze negocjator może sobie na to w danej sytuacji pozwolić (Podobas, 2014, s. 126).

Podstawą działania w obliczu manipulacji, wskazywaną przez wszystkich badaczy, jest znajomość technik manipulacji w celu ich rozpoznania. Jeśli znamy sztuczki, jakich może użyć wobec nas druga strona, jesteśmy w stanie rozpoznać je szybciej i odpowiednio zareagować. Ogólne zasady działania w obliczu manipulacji są następujące:

1) przygotuj solidną argumentację, trzymaj się faktów,

2) zachowaj spokój i opanowanie,

3) przejmij inicjatywę,

4) utrzymuj kontrolę nad przebiegiem rozmowy,

5) zwróć uwagę na postępowanie rozmówcy,

6) szukaj drogi porozumienia (Kałucki, 2018, s. 19).

Do zasad ochrony przed manipulacją możemy zaliczyć również:

- niepodejmowanie szybkich, nieprzemyślanych decyzji - w negocjacjach czy innych transakcjach zawsze obie strony powinny mieć czas na zastanowienie i wybór racjonalnego rozwiązania. W przypadku technik manipulacji negocjator 
poddawany jest presji, aby podjąć decyzję bez odpowiedniego zastanowienia się i przeanalizowania, dlatego nie należy godzić się na takie traktowanie,

- dobre przygotowanie do negocjacji - o tym, jak bardzo ważna jest pierwsza faza negocjacji, opowiada pierwsza część artykułu. W przypadku manipulacji konieczne jest koncentrowanie się na swoich podstawowych celach i warunkach brzegowych, co pomoże podjąć racjonalną decyzję,

- ujawnienie manipulacji - w czasie negocjacji ważne jest wykazywanie się asertywnością. Jeśli jedna strona czuje, że rozmówca próbuje wpłynąć na jej decyzje w nieetyczny sposób, może to głośno wyrazić. Powiedzenie otwarcie, że przejrzało się zachowanie drugiej strony, może spowodować zaniechanie używania przez nią manipulacji i powrót do normalnych, zrównoważonych rozmów,

- negocjacyjne ju-jitsu - czyli zastosowanie strategii opartej na wschodniej sztuce walki. Manipulowana strona może zmienić kierunek ataku, koncentrując siły negatywnego zachowania drugiej strony w negocjacjach na problemie, bez konieczności walki z tą siłą. Negocjacyjne ju-jitsu nawiązuje do jednej z przedstawionych już złotych zasad negocjacji - skupienia się na problemie, nie partnerze. Podstawę negocjacyjnego ju-jitsu stanowią: szukanie uzasadnienia stanowiska drugiej strony, zadawanie pytań, krytyka własnych pomysłów, czekanie (Niemczyk, Kędzierski, 2014, s. 126).

$\mathrm{Z}$ manipulacją w negocjacjach silnie wiążą się psychologiczne pułapki myślenia, opisywane często jako mechanizmy myślenia wolnego i szybkiego (Kahneman, 2012; Leboda, 2019).

Jest to wykorzystanie wiedzy dotyczącej działania mózgu, przetwarzania wiadomości, mechanizmów poznawczych oraz związanych z podejmowaniem decyzji, co może stanowić ogromną wartość w przypadku negocjacji.

Sposób myślenia zdeterminowany jest przez dwa mechanizmy: myślenie szybkie (tzw. myślenie w systemie 1) - oparte na emocjach i intuicji, automatyczne, oraz myślenie wolne (myślenie w systemie 2) - kontrolowane, wymagające wysiłku. Oba systemy pełnią potrzebną funkcję w naszym codziennym życiu, jednak pułapki związane z myśleniem szybkim mogą spowodować, że błędnie zostaną podjęte jakieś decyzje czy działania, co w negocjacjach może mieć daleko idące konsekwencje. Co więcej, jeśli jedna strona negocjacji jest świadoma błędów, na popełnienie których może być podatna druga strona, i umie tę wiedzę wykorzystać, może tak zmanipulować cały proces, aby osiągnąć korzyści jej kosztem.

D. Kahneman opisuje system 1 jako działanie w sposób szybki i automatyczny, bez wysiłku, bez świadomej kontroli nad naszymi decyzjami. Jest to mechanizm, którego ludzie używają bardzo często: przy wykonywaniu prostych obliczeń (np. 1+1), ocenianiu wielkości czy odległości, wykrywaniu emocji w głosie rozmówcy czy też ocenianiu drugiej strony na podstawie pierwszego wrażenia. Myślenie w tym systemie odbywa 
się w sposób szybki, ponieważ opiera się na schematach myślowych oraz tzw. heurystykach, czyli uproszczonych regułach wnioskowania - „myśleniu na skróty”. Schematami można określać posiadane wiadomości o otaczającym świecie, które zebraliśmy na podstawie życiowego doświadczenia. Schematy umożliwiają nam organizowanie rzeczywistości, dzięki czemu możemy komfortowo zachowywać się w znanych nam sytuacjach, nie mamy potrzeby uczyć się ponownie o tych samych miejscach, wydarzeniach czy ludziach. Schematy mają też zastosowanie w sytuacjach zupełnie nowych - pomagają ocenić, a następnie zakwalifikować dane zjawisko. Ułatwiają też zrewidowanie wieloznaczności informacji, przyjęcie jednej wersji wydarzeń. Im mniej mamy informacji o danym wydarzeniu, tym bardziej musimy uciekać się do schematów, aby wypełnić luki w naszej wiedzy.

System 2 jest $\mathrm{z}$ kolei charakterystyczny dla decyzji wymagających umysłowego wysiłku, wiąże się ze świadomym i kontrolowanym działaniem. Jest systemem podejmowania decyzji powolnym i ostrożnym. Ten system można włączać i wyłączać na własne życzenie, wymaga to jednak wysiłku, jako że wiąże się z koniecznością analizowania informacji oraz absorbuje uwagę. Tryb myślenia wolnego włącza się np. w momencie wykonywania bardziej skomplikowanych obliczeń, gdy planujemy ważną decyzje, pilnujemy, aby trafić samochodem w nowe miejsce. W kontekście negocjacji warto pamiętać, że w sytuacji zmęczenia czy rozproszenia trudniej jest podjąć wysiłek i pracować w systemie 2. Wykorzystują to techniki manipulacji, dlatego tak istotna jest możliwość niepodejmowania ważnych decyzji podczas silnego zmęczenia.

Głównym celem myślenia w systemie 2 jest sprawdzenie oraz weryfikacja myślenia automatycznego, dzięki czemu możemy dokonać korekt podjętych decyzji.

\section{Badanie porównawcze stylu negocjacji oraz podatności na manipulacje}

Odpowiedni styl negocjacji oraz znajomość technik manipulacji wydają się jednymi z czynników determinujących sukces w prowadzeniu pertraktacji. Badanie miało za zadanie sprawdzić, czy skuteczne negocjacje - rozumiane tutaj jako używanie stylu współpracy oraz mniejsza podatność na manipulację - są kompetencją, której można się nauczyć i doskonalić poprzez wiedzę teoretyczną i trening negocjacyjny. Zadanie to zostało zrealizowane przez analizę porównawczą wyników badania dla grupy związanej z negocjacjami oraz grupy bez takiego powiązania. Proces badawczy obejmujący przygotowanie ankiety, zbieranie wyników oraz poddanie ich analizie odbywał się w dniach 19-26.09.2019 r. Grupy badawcze:

a) grupa A - członkowie oraz alumni SKN Negocjator. Stanowili ją studenci i absolwenci w wieku 20-30 lat, którzy w chwili badania byli aktywnymi członkami 
SKN Negocjator lub jego alumnami - tj. podczas okresu studiowania udzielali się aktywnie w organizacji. SKN Negocjator jest to koło naukowe działające przy Szkole Głównej Handlowej w Warszawie od 1998 r., w pierwszych latach pod nazwą SKN Komunikacji, Negocjacji i Psychologii, co oddaje profil działalności koła - rozwój umiejętności miękkich, komunikacyjnych oraz negocjacyjnych,

b) grupa B - studenci i absolwenci niezwiązani z SKN Negocjator ani zawodowo z negocjacjami. Stanowili ją studenci i absolwenci w wieku 20-30 lat, różnych kierunków i różnych uczelni. Uczestnicy badania należący do tej grupy nie byli związani ze środowiskiem negocjacji, tj. nie byli członkami SKN Negocjator oraz nie byli związani zawodowo $\mathrm{z}$ negocjacjami.

Grupy badawcze zostały dobrane w taki sposób, aby możliwe było uzyskanie wyników porównawczych dwóch zbiorów: osób związanych z negocjacjami oraz osób, dla których temat ten jest obcy. Dzięki takiemu wyborowi możliwe były nie tylko sama analiza wyników, ale i porównanie odpowiedzi pomiędzy obiema grupami badanych, co pozwoliło na określenie wpływu doświadczeń negocjacyjnych na styl negocjacyjny oraz podatność na manipulację.

Czynniki mogące wpłynąć na weryfikację hipotez:

1. Nie wszyscy członkowie SKN Negocjator (grupa A) biorący udział w badaniu mieli wiedzę negocjacyjną - niektórzy ankietowani byli nowo przyjętymi działaczami, bez podstaw teoretycznej wiedzy negocjacyjnej.

2. Potencjalnie część badanych z grupy B to studenci kierunków, na których można nabyć wiedzę związaną z manipulacjami oraz skutecznymi negocjacjami.

3. Wszyscy badani z grupy A byli studentami bądź absolwentami Szkoły Głównej Handlowej, co ze względu na biznesowy charakter uczelni może implikować ich bardziej rywalizacyjny charakter w porównaniu z grupą B, która zrzesza studentów z różnych kierunków.

\section{Kwestionariusz - sekcja 1}

\section{Ankieta: Jaki jest Twój styl negocjacji?}

Sekcja pierwsza składała się z 30 pytań jednokrotnego wyboru dotyczących pośrednio bądź bezpośrednio konfliktu rozumianego w kontekście negocjacji, tj. jako częściowego konfliktu interesów. Zadaniem tego etapu ankiety było uszeregowanie poprzez system punktacji stylów negocjacji od najbardziej do najmniej charakterystycznych dla danej grupy docelowej. Badane style negocjacji to: unikanie, kompromis, łagodzenie, rywalizacja, współpraca. Pytania do ankiety w tej sekcji zostały 
zaczerpnięte z testu S. Chełpy i T. Witkowskiego Analiza stylów reagowania w sytuacjach konfliktowych.

Do każdego pytania odpowiedzi wybierano $\mathrm{z}$ listy, w czterech wariantach:

- zdecydowanie się nie zgadzam,

- raczej się nie zgadzam,

- raczej się zgadzam,

- zdecydowanie się zgadzam.

\section{Kwestionariusz - sekcja 2}

\section{Ankieta: Czy rozpoznasz manipulację?}

Sekcja druga składała się z 10 pytań jednokrotnego wyboru zawierających zdania związane $z$ technikami manipulacji. Pytania do ankiety powstały na podstawie rozdziału o technikach manipulacyjnych opisanych w O negocjacjach i negocjatorach (Niemczyk, Kędzierski, 2014) oraz innych pozycji z literatury przedmiotu.

Zadaniem tej części ankiety było sprawdzenie, która grupa docelowa lepiej poradziła sobie z rozpoznaniem manipulacji, tj. uzyskała więcej trafień.

Do każdego pytania odpowiedzi były wybierane z listy, w dwóch wariantach:

- tak,

- nie.

(Tak = podane zdanie jest manipulacją).

1. „Podsumowując, kupuje Pani dwa smartfony firmy X. Od razu zaproponuję dodatkowe, dedykowane słuchawki - jak Pani wie, smartfony te nie obsługują standardowych, więc proponuję zakup teraz, żeby nie przejmować się tym w przyszłości”.

2. „Dziękujemy za przedstawienie swoich warunków. Tak jak mówiliśmy, wydają się być racjonalne, jednak nie przewidywaliśmy, że poruszą Państwo temat X. W tej sytuacji musimy się skontaktować ze swoimi zwierzchnikami, ponieważ nie jesteśmy osobami decyzyjnymi".

3. „Co za niekompetencja z Państwa strony! Wy się chyba w ogóle nie znacie na temacie, te rozmowy nie mają sensu! Dobrze, że jestem cierpliwym człowiekiem, daję szansę to Państwu uratować".

4. „Jeśli nie chce Pan nic zamawiać, proszę tylko przejrzeć katalog z naszą nową ofertą. Opinia naszych najlepszych klientów jest bardzo ważna, co Pan o niej sądzi?”.

5. „Cieszę się, że w końcu doszliśmy do porozumienia! I my, i Państwo jesteśmy już zmęczeni. Przy umowach tego typu musicie jeszcze podpisać dodatkową zgodę na XY, to tylko $2 \%$ całej kwoty, więc załatwmy to sprawnie i rozejdźmy się do domów". 
6. „W takiej sytuacji prosimy o rabat $35 \%$. Jest to spora kwota, ale planujemy współpracę z Waszą firmą na lata i na pewno Wam się to opłaci".

7. „Cieszę się, że mogę z Panem podpisywać tę umowę! Już dawno nie miałem okazji porozmawiać tak otwarcie, i to z kimś o takiej wiedzy jak Pan. Wracając do negocjacji...".

8. „Na zakończenie tak udanych rozmów od firmy dorzucimy Państwu do zamówienia 20 dodatkowych jednostek gratis".

9. „Dziękuję za rozmowę. Zanim podpiszemy porozumienie, mam nadzieję, że wie Pani, że koszt dostawy, który już ustalaliśmy, pokrywamy tylko do $200 \mathrm{~km}$. Jest to zapisane w naszym regulaminie".

10. „Panie X, robimy razem interesy od trzech lat, znamy się jeszcze dłużej. Moim ostatnim życzeniem jest, żebyśmy robili sobie nawzajem problemy".

Każde $\mathrm{z}$ wymienionych $\mathrm{w}$ ankiecie zdań jest manipulacją i odpowiada konkretnej technice:

1) plasterki salami,

2) taktyka niepełnego pełnomocnictwa,

3) dobry i zły glina,

4) stopa w drzwiach,

5) podwieszenie,

6) drzwiami w twarz,

7) komplementowanie i podobieństwa,

8) osłodzenie oferty,

9) niska piłka

10) jowialność/bagatelizowanie.

\section{Analiza wyników badania - sekcja 1}

Style negocjacji dla grupy badawczej A - członków SKN Negocjator, przedstawia tabela 1.

Tabela 1. Hierarchia stylów dla grupy badawczej A na podstawie wyników ankiety

\begin{tabular}{|l|c|c|}
\hline \multicolumn{1}{|c|}{ Styl } & Suma uzyskanych punktów & Uporządkowanie rangowe \\
\hline Współpraca & 1296 & 1 \\
\hline Kompromis & 930 & 2 \\
\hline Unikanie & 850 & 3 \\
\hline Uleganie & 826 & 4 \\
\hline Rywalizacja & 692 & 5 \\
\hline
\end{tabular}

Źródło: badania własne. 
W badaniu przeprowadzonym za pomocą ankiety online wzięły udział 64 osoby.

Po uporządkowaniu rangowym stylów negocjacji na podstawie sumy punktów uzyskanych z badania z całą pewnością można stwierdzić, że styl współpracy jest stylem dominującym dla grupy A. Członkowie SKN Negocjator charakteryzują się kooperacyjnym i kompromisowym podejściem do negocjacji, natomiast styl rywalizacyjny okazał się mieć najmniejsze znaczenie.

Style negocjacji dla grupy badawczej B przedstawia tabela 2.

W badaniu przeprowadzonym za pomocą ankiety online wzięło udział 114 osób.

Tabela 2. Hierarchia stylów dla grupy badawczej B na podstawie wyników ankiety

\begin{tabular}{|l|c|c|}
\hline \multicolumn{1}{|c|}{ Styl } & Suma uzyskanych punktów & Uporządkowanie rangowe \\
\hline Współpraca & 2162 & 1 \\
\hline Kompromis & 1630 & 2 \\
\hline Unikanie & 1450 & 3 \\
\hline Rywalizacja & 1378 & 4 \\
\hline Uleganie & 1376 & 5 \\
\hline
\end{tabular}

Źródło: badania własne.

Po uporządkowaniu rangowym stylów negocjacji na podstawie sumy punktów uzyskanych z badania z całą pewnością można stwierdzić, że styl współpracy jest stylem dominującym również dla grupy B (tabela 3). Badani studenci charakteryzują się kooperacyjnym i kompromisowym podejściem do negocjacji, natomiast styl ulegania okazał się mieć najmniejsze znaczenie.

Tabela 3. Porównanie uzyskanych punktów per capita dla grup A i B - style negocjacji

\begin{tabular}{|l|c|c|}
\cline { 2 - 3 } \multicolumn{1}{c|}{} & Grupa A & Grupa B \\
\hline \multicolumn{1}{c|}{ Styl } & Suma uzyskanych punktów per capita & Suma uzyskanych punktów per capita \\
\hline Unikanie & 13,28 & 12,72 \\
\hline Kompromis & 14,53 & 14,30 \\
\hline Uleganie & 12,91 & 12,07 \\
\hline Rywalizacja & 10,81 & 12,09 \\
\hline Współpraca & 20,25 & 18,96 \\
\hline
\end{tabular}

Źródło: badania własne.

Aby zniwelować efekt dysproporcji w liczbie ankiet uzyskanych od grup badawczych, wyniki sprowadzono do wartości, które mogą zostać ze sobą porównane, tj. do średniej liczby punktów na jednego wypełniającego. Liczba ankiet nie miała 
wpływu na uszeregowanie rangowe, które przeprowadzono na podstawie wyników całościowych.

Wyniki przeprowadzonego badania wskazują duże podobieństwo w hierarchii stylów negocjacji pomiędzy badanymi grupami. Różnicą w uzyskanej hierarchii jest większa przewaga stylu ulegania nad rywalizacją dla grupy badawczej A w porównaniu z przewagą rywalizacji nad stylem ulegania dla grupy B (odpowiednio 4. i 5. miejsce). Najbardziej dominującym stylem negocjacji dla obu grup okazała się współpraca, czyli styl nastawiony na obopólną korzyść i uzyskanie porozumienia. Na 2. i 3. miejscu dla obu grup znalazły się odpowiednio styl kompromisu oraz styl unikania.

Wyniki badania wskazują na kooperatywne i kompromisowe podejście do tematu konfliktu interesów dla obu grup.

Istotne wydaje się, że hierarchia stylów dla grupy B przedstawia bardzo podobny schemat, różniąc się jedynie dwoma ostatnimi - tj. najmniej istotnymi - stylami.

Podatność na manipulację grupy badawczej A - członków SKN Negocjator (62 osoby) przedstawiają tabele 4 i 5.

Tabela 4. Wyniki liczbowe podatności na manipulację dla grupy A

\begin{tabular}{|l|r|r|r|r|r|r|r|r|r|r|}
\cline { 2 - 12 } \multicolumn{1}{c|}{} & \multicolumn{10}{c|}{ Numery twierdzeń } \\
\hline Odpowiedź & 1 & 2 & 3 & 4 & 5 & 6 & 7 & 8 & 9 & 10 \\
\hline tak & 44 & 20 & 58 & 32 & 62 & 32 & 46 & 14 & 20 & 36 \\
\hline nie & 20 & 44 & 6 & 32 & 2 & 32 & 18 & 50 & 44 & 28 \\
\hline
\end{tabular}

Źródło: badania własne.

Tabela 5. Wyniki punktowe per capita dla Grupy A

\begin{tabular}{|l|c|c|c|c|c|l|l|l|l|l|}
\hline & \multicolumn{10}{|c|}{ Numery twierdzeń } \\
\hline Odpowiedź & 1 & 2 & 3 & 4 & 5 & 6 & 7 & 8 & 9 & 10 \\
\hline tak=1 pkt & 0,69 & 0,31 & 0,91 & 0,50 & 0,97 & 0,50 & 0,72 & 0,22 & 0,31 & 0,56 \\
\hline nie=0 pkt & - & - & - & - & - & - & - & - & - & - \\
\hline Całkowicie: $5,69 / 10$ & & & & & & & & & & \\
\hline
\end{tabular}

Źródło: badania własne.

Podatność na manipulację grupy badawczej B (114 osób) przedstawiają tabele 6 i 7.

Aby zniwelować efekt dysproporcji w liczbie ankiet uzyskanych od grup badawczych, wyniki sprowadzono do wartości, które mogą zostać ze sobą zestawione, tj. średnia liczba punktów na jednego wypełniającego. 
Tabela 6. Wyniki liczbowe podatności na manipulację dla grupy B

\begin{tabular}{|l|r|r|r|r|r|r|r|r|r|r|}
\cline { 2 - 12 } \multicolumn{1}{c|}{} & \multicolumn{10}{c|}{ Numery twierdzeń } \\
\hline Odpowiedź & 1 & 2 & 3 & 4 & 5 & 6 & 7 & 8 & 9 & 10 \\
\hline tak & 70 & 26 & 98 & 70 & 100 & 78 & 78 & 36 & 24 & 84 \\
\hline nie & 44 & 88 & 16 & 44 & 14 & 36 & 36 & 78 & 90 & 30 \\
\hline
\end{tabular}

Źródło: badania własne.

Tabela 7. Wyniki punktowe per capita dla grupy B

\begin{tabular}{|l|l|l|l|l|l|l|l|l|l|l|}
\cline { 2 - 12 } \multicolumn{1}{c|}{} & \multicolumn{10}{c|}{ Numery twierdzeń } \\
\hline Odpowiedź & 1 & 2 & 3 & 4 & 5 & 6 & 7 & 8 & 9 & 10 \\
\hline tak=1 pkt & 0,61 & 0,23 & 0,86 & 0,61 & 0,88 & 0,68 & 0,68 & 0,32 & 0,21 & 0,74 \\
\hline nie =0 pkt & - & - & - & - & - & - & - & - & - & - \\
\hline Całkowicie: 5,82/10 & & & & & & & & & & \\
\hline
\end{tabular}

Źródło: badania własne.

Obie badane grupy uzyskały podobny wynik punktowy oscylujący wokół 6 pkt: grupa A - 5,69, grupa B - 5,82 na 10 możliwych do uzyskania, co sugeruje rozpoznawalność manipulacji na poziomie średnim/zadowalającym.

W obu badanych grupach wyraźną trudność sprawiały respondentom twierdzenia 2, 8 i 9, które reprezentują techniki: „niepełnego pełnomocnictwa”, „osłodzenia oferty” oraz „niskiej piłki”. Pokazuje to siłę tych metod, którymi można zmanipulować nawet osoby związane ze środowiskiem negocjacji. W przypadku pierwszych dwóch technik badani nie podejrzewali, że z pozoru niewinne działania partnera, tj. wstrzymywanie się od decyzji z powodu rzekomego braku pełnomocnictwa, „,bezinteresowny" prezent oraz dodatkowa informacja pod koniec rozmów, mogą być próbami manipulacji. Przypisać to można kooperacyjnemu i kompromisowemu stylowi, którym wykazały się obie badane grupy, i wynikającemu z tego podejściu opartemu na zaufaniu do partnera negocjacji.

\section{Podsumowanie}

Badanie przeprowadzone na podstawie kwestionariusza w przypadku dwóch grup badawczych pozwoliło potwierdzić część postawionych hipotez związanych ze stylem negocjacji.

Hipoteza 1. Dominujacym stylem grupy trenujacej negocjacje jest styl wspótpracy, a najmniej dominującym - styl rywalizacji, co zwiqzane jest z posiadaną teoretyczna wiedzą i doświadczeniami na temat korzyści płynacych z takiego nastawienia. 
Wykazano, że grupa badawcza A, do której należą członkowie i alumni organizacji związanej z negocjacjami, uzyskała wyższe wartości punktowe przy stylach współdziałania oraz kompromisu, a mniejsze w stylu rywalizacji niż grupa badawcza B.

Świadczy to o tym, że wiedza teoretyczna związana z negocjacjami przekłada się na wyższe szanse przeprowadzenia skutecznych negocjacji, tzn. takich, które zakończą się porozumieniem. Zbieżność hierarchii stylów negocjacyjnych wśród obu badanych grup ukazuje również pozytywne zjawisko, że osoby nawet bez treningu negocjacyjnego i wiedzy o zaletach rozwiązań typu win-win dążą do wspólnego działania na zasadach partnerstwa.

Hipoteza 2. Grupa trenująa negocjacje odznacza się bardziej kooperacyjnym oraz kompromisowym stylem negocjacji niż nietrenująca.

Grupa badawcza A odznaczała się bardziej kooperacyjnym oraz kompromisowym stylem negocjacji niż grupa B, co znalazło potwierdzenie w przeprowadzonym badaniu. O ile hierarchia stylu współpracy oraz kompromisu była taka sama dla obu badanych grup (odpowiednio 1. i 2. miejsce), o tyle wynik punktowy był wyższy dla grupy A: styl współpracy: 20,25 vs. 18,96 pkt per capita, co stanowi największą różnicę w niniejszym badaniu (1,29 pkt), styl kompromisu: 14,53 vs. 14,30 pkt per capita.

Hipoteza 3. Grupa nietrenująca negocjacji będzie się odznaczała bardziej rywalizacyjnym stylem negocjacji niż grupa trenująca, co zwiq̨zane jest z tendencją ludzi do dążenia do wygranej oraz postrzegania konfliktu interesów w kategorii „twój zysk= moja strata”.

Hipoteza ta również została potwierdzona. Styl rywalizacji jest najmniej charakterystycznym dla grupy A (5. miejsce), natomiast w grupie B zajmuje on miejsce o jedno wyższe (4.). Ponadto różnica per capita w kategorii stylu rywalizacji dla obu badanych grup jest drugą najwyższą (1,28 pkt).

Wyniki sekcji 1 pokazują, że trening umiejętności negocjacyjnych i teoretyczne podstawy negocjacji mogą mieć pozytywny wpływ na styl negocjacyjny, co jest czynnikiem przyczyniającym się do skutecznych negocjacji.

Wynik badania oraz fakt, że jest on w obu grupach zbliżony, może świadczyć o tym, że próby manipulacji są trudne do wykrycia bez kontekstu wcześniejszej rozmowy. Kolejnym czynnikiem utrudniającym wykrycie nieszczerości czy ukrytych zamiarów stanowi komunikacja niewerbalna. $Z$ komunikatów niewerbalnych, często intuicyjnie, negocjator jest w stanie wychwycić potencjalne zagrożenie i odpowiednio mu przeciwdziałać. Wynik uzyskany w kwestionariuszu również przemawia za tym, że rozpoznanie manipulacji jest zadaniem trudnym nawet dla osób, które mają teoretyczne podstawy negocjacji.

Wyjaśnieniem niewielkiej przewagi punktowej badanej grupy B nad grupą A może być wspomniana kwestia stylu negocjacyjnego, który jest nieco bardziej współpracujący i kompromisowy niż grupy B. Grupa B uzyskała wyraźnie większą liczbę punktów w stylu rywalizacyjnym oraz wyraźnie mniejszą w stylu współpracującym, co 
może się przekładać na bardziej agresywne i mniej ufne podejście do partnera negocjacji, a w konsekwencji - większą skłonność do wnioskowania, że druga strona chce nami manipulować.

Hipoteza 4. Grupa trenujaca negocjacje lepiej wykrywa manipulacje, co zwiqzane jest z teoretycznq wiedza na temat technik manipulacji; grupa niezwiq̨zana ze środowiskiem negocjacji - osiagnie słabsze wyniki w wykrywaniu manipulacji niż pierwsza.

Druga część badania związana z manipulacjami nie potwierdziła hipotezy, że wyniki grupy badawczej A miały być lepsze niż grupy B. Były one jednak bardzo zbliżone, wyraźnie pokazując, przy których technikach manipulacji badani mieli problem.

Wyniki przedstawiały zadowalający poziom rozpoznania manipulacji wśród obu grup, w przybliżeniu wynosząc 6 rozpoznań na 10 podanych manipulacji. Rezultat ten pokazuje miarę wyzwania, jakimi są negocjacje w sytuacji prowadzenia rozmów podszytych manipulacją. Okazuje się, że trudnością jest nie tylko odpowiednia obrona przed konkretnymi technikami manipulacji, ale jak wynika z badania - samo zauważenie, że druga strona stosuje wobec nas nieczyste zagrywki.

\section{Bibliografia}

Kahneman, D. (2012). Pułapki myślenia: o myśleniu szybkim i wolnym. Poznań: Media Rodzina.

Kałucki, K. (2018). Techniki negocjacyjne. Warszawa: Difin.

Kowalczyk, E. (2017). Wykorzystanie i percepcja dwuznacznych etycznie technik negocjacyjnych. Organizacja i Kierowanie, 1(175), 133-149.

Lakhani, D. (2007). Perswazja: sztuka zdobywania tego, czego pragniesz. Gliwice: Wydawnictwo Helion.

Leboda, D. (2019). Pułapki myślenia. Jak ich unikać?, https://www.focus.pl/artykul/ pulapki-myslenia?page=1 (dostęp: 14.09.2019).

Lewicki, R.J., Saunders, M., Barry, B., Minton, J.W. (2005). Zasady negocjacji. Kompendium wiedzy dla trenerów i menedżerów. Poznań: Dom Wydawniczy Rebis.

Mayer, R. (2007). Jak wygrać każde negocjacje. Warszawa: MT Biznes.

Niemczyk, A., Kędzierski, M. (2014). O negocjacjach i negocjatorach: poradnik praktyka. Gliwice: Helion.

Olechnicki, K., Załęcki, P. (1997). Stownik socjologiczny. Toruń: Graffitti BC.

Podobas, I. (2014). Negocjacje i mediacje w pracy socjalnej. Warszawa: Centrum Rozwoju Zasobów Ludzkich.

Ury, W. (2006). Odchodzac od nie. Warszawa: PWE. 


\begin{abstract}
Negotiation Competences of Students Versus Negotiation Style and Susceptibility to Manipulation

The subject of the article is the patterns of thinking and acting which enable us to organize reality so that we can behave comfortably in familiar situations, events, or environments. The effectiveness of these schemas was verified in relation to negotiation competence and experience in recognizing and defending against manipulation among university students and graduates. Conflict response tests and descriptions of 10 manipulative situations were used in the survey. Two groups of respondents were surveyed - negotiation-trained and untrained and professional non-negotiators.

It was shown that the research group, which includes members and alumni of a negotiationrelated organisation, scored higher on the cooperation and compromise styles and lower on the competition style than the non-trained research group.

The second part of the study related to manipulation gave very similar results, clearly showing at with manipulation techniques the respondents had problems. The results themselves presented a satisfactory level of manipulation recognition among both groups, approximately amounting to 6 recognitions for every 10 manipulations given.
\end{abstract}

Keywords: negotiation competences, manipulation, negotiation

\title{
Dr Grzegorz Myśliwiec
}

Adiunkt w Zakładzie Zachowań Organizacyjnych, w Instytucie Kapitału Ludzkiego SGH. Jego zainteresowania naukowe skupiają się wokół komunikacji interpersonalnej w biznesie i administracji. Główne publikacje to: Techniki i triki negocjacyjne (2007), Warszawa: Difin; Etyka gospodarcza i zawodowa (2013), Warszawa: Wydawnictwo Almamer; Savoir-vivre w administracji (2010), Warszawa: Wydawnictwo INFOR. Animator studenckiego ruchu naukowego, organizator i sędzia turniejów negocjacyjnych. Koordynator sektora ochrony zdrowia w badaniach sektorowych kompetencji pracowniczych IKL w latach 2013-2016.

e-mail: gmysli@sgh.waw.pl

\section{Mgr Adrianna Załęcka}

absolwentka Szkoły Głównej Handlowej w Warszawie, prezeska Studenckiego Koła Naukowego Negocjator. 